\title{
Effect of prenatal treatment with busulfan on the hypothalamo-pituitary axis, genital tract and testicular histology of prepubertal male rats
}

\author{
Marie-Claude Viguier-Martinez, Marie-Thérèse Hochereau-de Reviers*, \\ B. Barenton† and Christine Perreau*
}

Laboratoire de Physiologie Comparée, Faculté des Sciences, Parc de Grandmont, 37200 Tours,

*Station de Physiologie de la Reproduction, I.N.R.A., Nouzilly, 37380 Monnaie, and

$\dagger$ Ecole Nationale Supérieure d'Agronomie, I.N.R.A., 9 place Pierre Viala, 34060 Montpellier Cedex, France

\begin{abstract}
Summary. Female Wistar rats were treated with busulfan or with solvent on Day 20 of pregnancy. Thirty male offspring of each group were killed at 38 days of age. In busulfan-treated rats, compared to controls, hypothalamic LH-RH content was decreased by $52 \%$, whereas pituitary LH and FSH concentrations were increased by 60 and $43 \%$ respectively. Plasma $\mathrm{LH}$ and FSH were increased by 112 and $275 \%$ respectively. Prolactin concentrations were not changed, but plasma testosterone concentration was decreased by $48 \%$. The total number of Leydig cells per testis was decreased by $52 \%$, and LH binding sites per testis were decreased by $70 \%$. The total number of Sertoli cells was decreased by $44 \%$, while FSH binding sites per testis were decreased by $62 \%$. Spermatogenesis was practically absent after prenatal exposure to busulfan. These data demonstrate that on Day 20 of pregnancy all the dividing cells in the fetal testes were depleted by an antimitotic treatment. The stimulation of the hypothalamo-pituitary axis could have been partly induced by the decrease in testosterone production, and by the aplasia of germ cells involving modifications of the remaining Sertoli and Leydig cells.
\end{abstract}

\section{Introduction}

Germinal cell aplasia (or Sertoli cell-only syndrome) can be experimentally induced in different ways, e.g. by fetal irradiation, heat sterilization, experimental cryptorchidism, ligation of the testicular efferent ducts, vitamin A deficiency, or treatment with an alkylating compound such as busulfan (de Kretser, Kerr, Rich, Risbridger \& Dubos, 1980).

Busulfan forms cross-links in DNA in mitotic cells, and so induces chromosomal aberrations and death of cells in proliferative tissues. Treatment of pregnant rats with busulfan produces sterile male offspring (Jackson, Partington \& Fox, 1962; Jackson, 1970). Busulfan treatment on Day 20 of pregnancy (Gillet \& Laporte, 1973a) leaves very few germ cells in the embryonic testis. Germ cell aplasia stimulates the hypothalamo-pituitary axis (Franchimont $e$ t al., 1972). The aim of this experiment was to correlate the endocrinological status of prepubertal male rats with the activity of Leydig cells and Sertoli cells in the almost total absence of germ cells. The growing male rat was chosen because its hypothalamo-pituitary axis is more sensitive to the negative feedback of testosterone than that of the adult rat (Bloch, Masken, Kragt \& Ganong, 1974; Negri \& Gay, 1976; Caraty, Martinat \& Blanc, 1981a). 


\section{Materials and Methods}

Animals. Two groups of 12 pregnant female Wistar rats were treated on Day 20 of pregnancy. In Group I, rats received one subcutaneous (s.c.) injection of busulfan, $20 \mathrm{mg} / \mathrm{kg}$ (Techni-Pharma, Monaco). In Group II, the rats received one s.c. injection of solvent (olive oil-benzyl alcohol, $9: 1$, $\mathrm{v} / \mathrm{v}$ ). Thirty male offspring from Group I and 30 from Group II were killed by decapitation at 38 days of age. Testes, epididymides, ventral prostate and seminal vesicle glands were immediately dissected out and weighed. Blood samples were collected from the neck section, centrifuged and deep frozen until radioimmunoassay for LH, FSH, prolactin and testosterone. Hypothalami and pituitaries were dissected out, homogenized in $0.1 \mathrm{~N}-\mathrm{HCl}$ for hypothalami, or distilled water for pituitaries, and then frozen until radioimmunoassay for LH-RH content (hypothalami) and for gonadotrophin concentrations (pituitaries). The limits of the hypothalamic samples were defined as the optic chiasma rostrally, the hypothalamic fissures laterally and the mamillary bodies posteriorly. Each hypothalamic section was approximately $2-3 \mathrm{~mm}$ in depth.

Radioimmunoassays. Pituitaries and plasma samples were analysed for FSH content using a specific radioimmunoassay kit for rat FSH (NIAMDD) and for LH content using a specific doubleantibody radioimmunoassay as previously described (Viguier-Martinez, 1976). The results were expressed in terms of NIAMDD-rat-FSH-RP1 for FSH, and purified rat LH-SX-1-1 for LH. One unit of LH-SX-1-1 was equivalent to 1.58 units of NIH-LH-S11. The detection limit was $100 \mathrm{ng} / \mathrm{ml}$ for FSH and $0.6 \mathrm{ng} / \mathrm{ml}$ for LH; the intra-assay coefficients of variation were $10 \%$ for $\mathrm{LH}$ and FSH. Plasma levels of prolactin were measured using a specific radioimmunoassay (Martinat, Hall, Ravault \& Dubois, 1979). The potency of the standard (PRL-I.N.R.A.) was about twice that of the NIAMDD-rat-PRL-RP1. The detection limit was $0.3 \mathrm{ng} / \mathrm{ml}$ and the intra-assay coefficient of variation was $10 \%$. Plasma testosterone was measured after solvent extraction using a radioimmunoassay as previously described (Caraty, de Reviers, Martinat \& Blanc, 1981b). The intra-assay coefficient of variation was $6 \%$ and the detection limit $50 \mathrm{pg} / \mathrm{ml}$. LH-RH content was estimated by a specific radioimmunoassay (Caraty, de Reviers, Pelletier \& Dubois, 1980). The intra-assay coefficient of variation was $8 \%$ and the detection limit $4 \mathrm{pg} / \mathrm{ml}$. All samples of each hormone were processed in duplicate. The hormone concentrations of plasma samples were determined using logit-log transformation.

Testicular LH and FSH receptors. Numbers of $\mathrm{LH}$ and FSH receptor sites were measured from a pool of testicular membranes (10 testes per group) as the protein content per rat testis was not sufficient to perform individual assays.

Crude plasma membranes were prepared as previously described for the ram by Barenton \& Pelletier (1980). Membrane proteins were measured by the method of Lowry, Rosebrough, Farr \& Randall (1951) using bovine serum albumin (BSA) as reference, after hydrolysis of the membranes for $1 \mathrm{~h}$ at $65^{\circ} \mathrm{C}$ in $0 \cdot 1 \mathrm{~N}-\mathrm{NaOH}$. Testicular $\mathrm{LH}$ and $\mathrm{FSH}$ receptor numbers were measured as previously described (Viguier-Martinez, Hochereau-de Reviers, Barenton \& Perreau, 1983). The detection limit was $0.2 \mathrm{fmol} / \mathrm{mg}$ protein for $\mathrm{LH}$ receptors, and $0.5 \mathrm{fmol} / \mathrm{mg}$ protein for FSH receptors; the intra-assay coefficient of variation was $8 \%$ for both assays.

Testicular histology. In each group, one testis of each rat was fixed in Bouin-Hollande solution. Histological analyses were performed on 5 animals chosen within the range of the mean testicular weight \pm s.e.m. for each group. Intertubular and tubular tissues were analysed as described previously (Hochereau-de Reviers, Loir \& Pelletier, 1976; Hochereau-de Reviers et al., 1979). The total number of Sertoli cells per testis was corrected according to Abercrombie (1946).

Statistical methods. Hormonal levels and histological data were analysed using Student's $t$ test. The level of significance is noted in each figure or table.

Body weight and organ weights

\section{Results}

Prenatal treatment with busulfan decreased testicular weight by $80 \%(P<0.001$; Text-fig. 1a). Body weight and the weights of the epididymis, ventral prostate 3 and seminal vesicles were 3 also $01: 38 \mathrm{Am}$ 

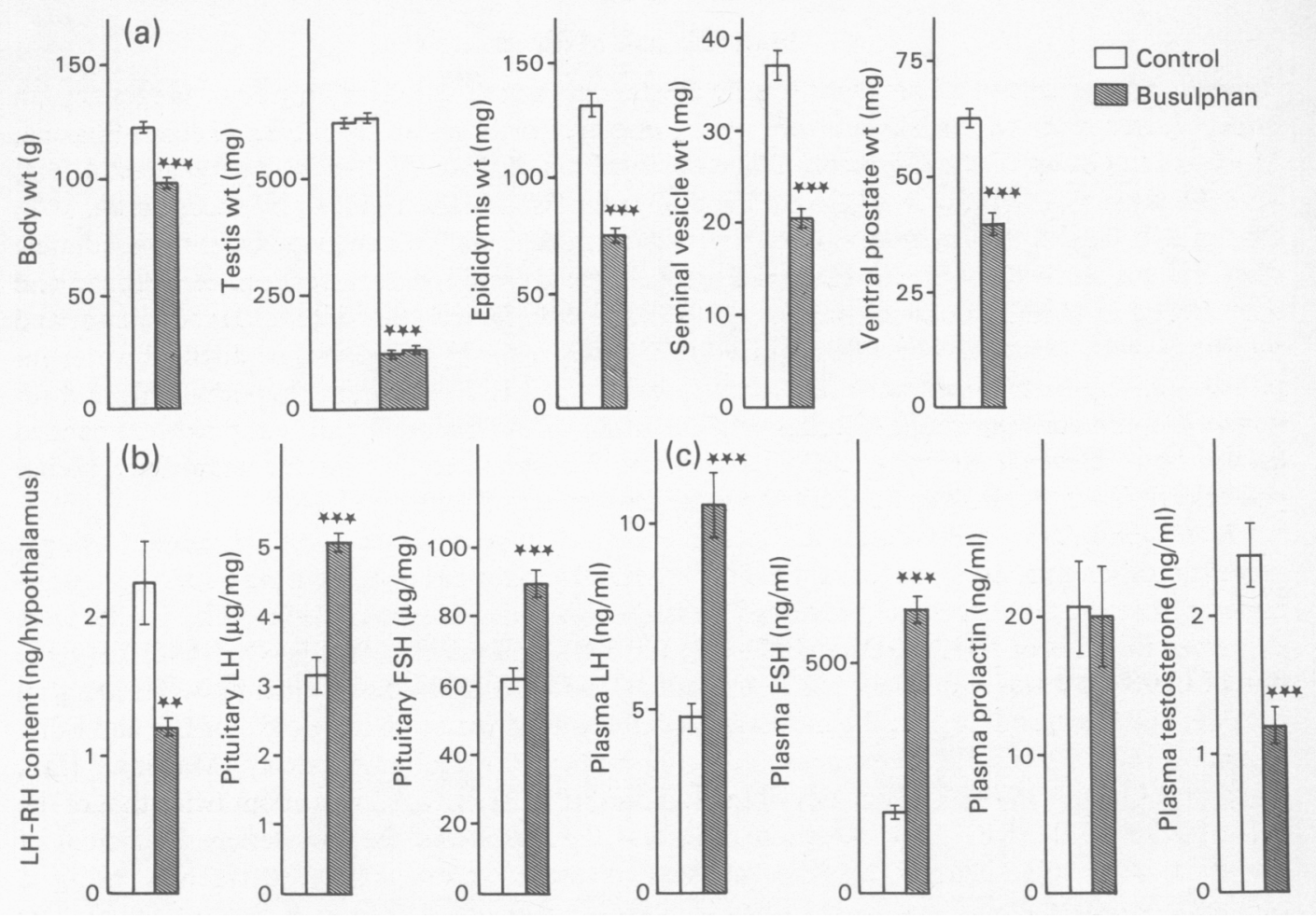

Text-fig. 1. Effect of prenatal treatment with busulfan on body weight and other characteristics in 38-day-old male rats. Values are mean \pm s.e.m. for 30 rats/group (a, c) or 10 rats/group (b). ${ }^{* *} P<0.01,{ }^{* * *} P<0.001$. For testicular weight, left and right testis have been weighed separately.

decreased by the treatment, but to a lesser extent : by $20 \%$ for body weight, by $42 \%$ for epididymis weight, by $45 \%$ for seminal vesicle weight and by $36 \%$ for ventral prostate weight, compared with values for control rats.

\section{Hypothalamo-pituitary axis}

Hypothalamic LH-RH content was significantly decreased in treated rats by about $52 \%$ $(P<0.01$; Text-fig. 1b). In contrast, the pituitary content of gonadotrophin was significantly increased, LH by $60 \%(P<0.001)$ and FSH by $43 \%(P<0.001)$.

Plasma gonadotrophin concentrations were also significantly increased after busulfan treatment $(P<0.001$, Text-fig. 1c), LH by $122 \%$ and FSH by $275 \%$. Plasma testosterone concentration was significantly decreased by $48 \%$ in treated rats $(P<0.001)$. There was no significant difference in plasma prolactin concentrations between control and treated rats.

\section{Testicular histology}

The total volumes of intertubular tissue and of Leydig cells per testis decreased by about $73 \%$ compared with controls (Table 1).

The areas of Leydig cell cytoplasm were slightly, but significantly $(P<0.01)$, decreased in the treated rats, but the areas of Leydig cell nuclei were not modified by the treatment, resulting in an increased nucleus-cytoplasmic ratio compared with control rats. The total number of Leydig cells

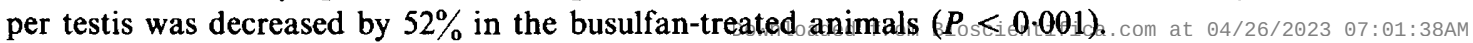


The mean diameter of the seminiferous tubules was decreased by $33 \%(P<0.001)$ and the total length of seminiferous tubules was decreased by $63 \%(P<0.001)$ in treated rats as compared with control rats.

In 2 of the 5 animals analysed, germinal cells were absent in all the seminiferous tubules, and in the remaining 3 , germ cells were present in $4 \%$ of the seminiferous tubules. The total number of Sertoli cells per testis in treated animals was only $44 \%$ of the total number present in controls $(P<0.01)$. The mean area of Sertoli cell nuclei was decreased by $16 \%$ in treated animals $(P<0.001)$. The Sertoli cells in the $4 \%$ of normal tubules in the busulfan-treated animals had a slightly greater area $(11 \%, P<0.01)$, as compared with the other tubules of the same animals, but this area was still lower $(8 \%, P<0.01)$ when compared to control animals. These tubules were morphologically normal, with all the steps of spermatogenesis present. However, the daily production of primary spermatocytes at 38 days of age by the few normal tubules in the treated animals was very small $\left(0.2 \times 10^{6} /\right.$ day $)$ when compared with control animals $\left(46.0 \times 10^{6} /\right.$ day $)$.

\section{Gonadotrophin receptors}

The binding affinities $\left(K_{\mathrm{a}}\right)$ of $\mathrm{LH}$ and FSH to their respective testicular receptors were not affected by the treatment (Table 2). Scatchard plots were linear, indicating only one class of

Table 1. Effect of prenatal treatment with busulfan on testicular histology of 38-day-old male rats

\begin{tabular}{|c|c|c|c|c|}
\hline & $\begin{array}{l}\text { Control } \\
\text { rats }\end{array}$ & $\begin{array}{l}\text { Busulfan- } \\
\text { treated rats }\end{array}$ & Decrease & Significance \\
\hline Testicular weight (mg) & $644 \cdot 0 \pm 27 \cdot 0$ & $116.0 \pm 8.0$ & $82 \%$ & $P<0.001$ \\
\hline Intertubular tissue volume $\left(\mathrm{mm}^{3}\right)$ & $55.0 \pm 3.0$ & $14.8 \pm 1.7$ & $73 \%$ & $P<0.001$ \\
\hline \multicolumn{5}{|l|}{ Leydig cells } \\
\hline Total volume/testis $\left(\mathrm{mm}^{3}\right)$ & $20 \cdot 0 \pm 1 \cdot 2$ & $7 \cdot 4 \pm 0.8$ & $63 \%$ & $P<0.01$ \\
\hline Total no./testis $\left(\times 10^{6}\right)$ & $4.4 \pm 0.4$ & $2 \cdot 1 \pm 0.2$ & $52 \%$ & $P<0.001$ \\
\hline Cytoplasmic area $\left(\mu \mathrm{m}^{2}\right)$ & $71 \cdot 0 \pm 2 \cdot 0$ & $61.2 \pm 0.9$ & $14 \%$ & $P<0.01$ \\
\hline Nuclear area $\left(\mu \mathrm{m}^{2}\right)$ & $25 \cdot 0 \pm 1 \cdot 3$ & $26.2 \pm 0.6$ & - & NS \\
\hline \multicolumn{5}{|l|}{ Seminiferous tubules } \\
\hline Total length (m) & $11 \cdot 8 \pm 1 \cdot 1$ & $4.3 \pm 0.2$ & $63 \%$ & $P<0.001$ \\
\hline Diameter $(\mu \mathrm{m})$ & $199.0 \pm 2.7$ & $133.0 \pm 5.0$ & $33 \%$ & $P<0.001$ \\
\hline \multicolumn{5}{|l|}{ Daily production of primary } \\
\hline spermatocytes/testis $\left(\times 10^{6}\right)$ & $46 \cdot 0 \pm 4 \cdot 0$ & $0.2 \pm 0.1$ & $99 \%$ & $P<0.001$ \\
\hline \multicolumn{5}{|l|}{ Sertoli cells } \\
\hline Total no./testis $\left(\times 10^{6}\right)^{*}$ & $28 \cdot 1 \pm 3 \cdot 0$ & $15 \cdot 7 \pm 0 \cdot 3$ & $44 \%$ & $P<0.01$ \\
\hline Nuclear area $\left(\mu \mathrm{m}^{2}\right)$ & $52.0 \pm 1.0$ & $43.6 \pm 0.9$ & $16 \%$ & $P<0.001$ \\
\hline
\end{tabular}

Values are mean \pm s.e.m. ( 5 testes per group).

* Corrected for nuclear size.

NS, not significant.

Table 2. Effect of prenatal treatment with busulfan on testicular gonadotrophin receptors* of 38-day-old male rats

\begin{tabular}{|c|c|c|c|c|c|c|c|c|}
\hline & \multirow[b]{2}{*}{$\begin{array}{c}K_{\mathrm{a}} \text { for } \mathrm{LH} \\
\text { receptors } \\
\left(10^{10} \mathrm{M}^{-1}\right)\end{array}$} & \multicolumn{3}{|c|}{ No. of $\mathrm{LH}$ receptor sites } & \multirow[b]{2}{*}{$\begin{array}{c}K_{\mathrm{a}} \text { for FSH } \\
\text { receptors } \\
\left(10^{10} \mathrm{M}^{-1}\right)\end{array}$} & \multicolumn{3}{|c|}{ No. of FSH receptor sites } \\
\hline & & $\begin{array}{c}\mathrm{fmol} / \mathrm{mg} \\
\text { protein }\end{array}$ & $\mathrm{fmol} /$ testis & $\begin{array}{l}\text { Binding } \\
\text { sites/ } \\
\text { Leydig } \\
\text { cell }\end{array}$ & & $\begin{array}{c}\mathrm{fmol} / \mathrm{mg} \\
\text { protein }\end{array}$ & $\mathrm{fmol} /$ testis & $\begin{array}{l}\text { Binding } \\
\text { sites/ } \\
\text { Sertoli } \\
\text { cell }\end{array}$ \\
\hline Control rats & 6.80 & $9 \cdot 08$ & $58 \cdot 80$ & 8045 & 1.60 & $14 \cdot 50$ & $94 \cdot 20$ & 2018 \\
\hline Busulfan-treated rats & 5.97 & $29 \cdot 32$ & $17 \cdot 70$ & 5074 & $1 \cdot 11$ & $59 \cdot 40$ & 35.80 & 1373 \\
\hline
\end{tabular}

* Numbers of LH and FSH receptor sites were measured for a pool of testicular membranes (10 testes per group). 
binding sites for each hormone. The total number of LH binding sites, expressed per mg of membrane protein, was increased by $223 \%$ in treated animals as compared with controls. Conversely, the total number of LH binding sites per testis was decreased by $70 \%$, and the number estimated for Leydig cells was decreased by about $37 \%$ in treated animals. The total number of FSH binding sites, expressed per mg membrane protein, was increased by $309 \%$ in the treated animals, corresponding to a decrease of $62 \%$ when expressed per whole testis and a reduction of about $32 \%$ when expressed per Sertoli cell.

\section{Discussion}

As previously shown in older male rats (Hall \& Gomes, 1973), prenatal exposure to busulfan induces a decrease in plasma concentrations of testosterone. The significant decrease in hypothalamic LH-RH content may be a consequence of decreased negative feed-back by testosterone, stimulating the rate of discharge of hypothalamic LH-RH more than the rate of synthesis. Such an increase in LH-RH release has been previously observed after castration of prepubertal (38 days) and adult (121 days) rats (Payne, Kelch, Murono \& Kerlan, 1977; Badger, Wilcox, Meyer, Bell \& Cicero, 1978). A low level of negative feed-back of testosterone, an increase in LH-RH concentration in pituitary portal blood (Eskay, Mical \& Porter, 1977) and perhaps an increase in pituitary sensitivity to LH-RH could explain the large increase in pituitary and plasma gonadotrophins. This response was greater in our animals than that observed in adult rats by Gomes, Hall, Jain \& Boots (1973). This was to be expected because, as has been shown previously by many authors, the hypothalamo-pituitary axis of the young rat is more sensitive to inhibition by testosterone than is that of the adult rat (Bloch et al., 1974; Negri \& Gay, 1976; Caraty et al., 1981a). Plasma prolactin concentration was not affected by prenatal exposure to busulfan, indicating that neither testosterone level nor Sertoli and germ cell depletion affect prolactin secretion.

A drastic decrease in the weight of the testis and seminal vesicles has been previously observed by Hall \& Gomes (1973) and a similar decrease in the weight of the testis and epididymis by Gillet \& Laporte (1973a, b). The low concentration of testosterone probably accounts for this retarded development of the accessory sex organs.

Intertubular tissue volume was reduced by $73 \%$, and this decrease was greater than the decrease in the total volume of Leydig cells, which was about $63 \%$. This difference probably reflects a deterioration in the lymphatic and blood vessel supply to the intertubular tissue. While the total number of Leydig cells was affected by the treatment, the cytoplasmic and nuclear areas of the Leydig cells hardly differed from those of control rats. The large decrease in testicular LH receptors, expressed as fmol/testis, may be related to the decrease in the total number of Leydig cells per testis. When expressed as fmol/Leydig cell, the number of testicular LH receptors was reduced by only $37 \%$. These results are comparable to those observed after $\mathrm{X}$-irradiation of the male fetus (Rich \& de Kretser, 1979) and may be due to the high plasma LH level inducing a downregulation (Haour \& Saez, 1977). The observed decrease in testosterone secretion may result mainly from the decrease in the total number of Leydig cells, and only partly from the decrease in the number of LH receptors per Leydig cell.

A significant decrease in the total length of seminiferous tubules per testis, and in their diameter, was induced by busulfan treatment, as previously observed by other authors (Gillet $\&$ Laporte, 1973a; Hall \& Gomes, 1973). The daily production of primary spermatocytes, estimated on the few normal seminiferous tubules remaining after treatment, was practically zero, and the total population of Sertoli cells was decreased by $44 \%$ in busulfan-treated rats. The nuclear size of the Sertoli cells, which is related to their functional activity (Vendrely, Guerillot \& Dalage, 1972), was reduced in Sertoli cell-only tubules, while it tended to be normal in the few normal tubules of treated rats. This suggests an active interaction between germ cells and Sertoli cell differentiation. The decrease in number of FSH receptors per testis $(62 \%)$ was greater than that of Sertoli cells per 
testis $(44 \%$ ), but not comparable to that of germ cells (about $99 \%$ ). This suggests that FSH receptors are mainly located on Sertoli cells.

In the rat fetus, the maximum proliferation of Sertoli cells occurs on Day 20 of pregnancy (Orth, 1982), while the Leydig cell population is formed later, between 25 and 60 days of age (Bergh \& Damber, 1978). Busulfan treatment could act first by a direct effect, the destruction of a large proportion of the dividing cells in utero (germ cells, Sertoli cells and precursors of Leydig cells) resulting in a lower number of somatic and germ cells at birth. Our results suggest that the depletion in germ cells induced by busulfan impairs the development and functional activity of the remaining Sertoli and Leydig cells.

Sterilization induced by busulfan treatment has consequences comparable with those induced cryptorchidism: elevation of plasma gonadotrophin concentration (Gomes \& Jain, 1976) and a decrease in the number of LH and FSH receptors (Hagenäs, Ritzén, Svensson, Hansson \& Purvis, 1978). However, the plasma concentration of testosterone remained normal in cryptorchid rats (Schanbacher, 1980). This suggests that treatment with busulfan during gestation, or X-irradiation of the fetus (Rich \& de Kretser, 1977), has a more dramatic effect than cryptorchidism on the structure and activity of the rat testis.

This work was supported by funds from the Institut National de la Recherche Agronomique, from the Centre National de la Recherche Scientifique, and from the Faculté des Sciences (Tours). Busulfan, rat FSH radioimmunoassay kit, testosterone antiserum, purified rat LH-SX-1-1, rat LH antiserum and ${ }^{125} \mathrm{I}$-labelled $\mathrm{hCG}$ were generously supplied by Techni-Pharma Laboratories (Monaco), NIAMDD (Bethesda, Maryland), Dr G. Picaper, Dr M. Jutisz, Dr M. Dubois and Dr F. Haour, respectively. We thank Mrs N. Martinat for the prolactin assay; Mr A. Caraty for the LHRH assay; Dr G. Montgomery for help with the English; and Mrs E. Raynaud for typing the manuscript.

\section{References}

Abercrombie, M. (1946) Estimation of nuclear population from microtome sections. Anat. Rec. 94, 238248.

Badger, T.M., Wilcox, C.E., Meyer, E.R., Bell, R.D. \& Cicero, T.J. (1978) Simultaneous changes in tissue and serum levels of luteinizing hormone, folliclestimulating hormone and luteinizing hormone/ follicle-stimulating hormone releasing factor after castration in the male rat. Endocrinology 102, 136141.

Barenton, B. \& Pelletier, J. (1980) Prolactin, testicular growth and $\mathrm{LH}$ receptors in the ram following light and 2-Br- $\alpha$-ergocryptine (CB-154) treatments. Biol. Reprod. 22, 781-790.

Bergh, A. \& Damber, J.E. (1978) Morphometric and functional investigation on the Leydig cells in experimental cryptorchidism in the rat. Int. J. Androl. 1, 549-562.

Bloch, G.J., Masken, J., Kragt, C.L. \& Ganong, W.F. (1974) Effect of testosterone on plasma LH on male rats of various ages. Endocrinology 94, 947-958.

Caraty, A., de Reviers, M.M., Pelletier, J. \& Dubois, M. (1980) Reassessment of radioimmunoassay of LRF in plasma and hypothalamic extract of rats and rams. Reprod. Nutr. Develop. 20, 1489-1501.

Caraty, A., Martinat, N. \& Blanc, M. (1981a) Effect of age on the hypothalamo-hypophyseal response to castration and cryptorchidism in the male rat. IRCS Med. Sci. 9, 39-40.
Caraty, A., de Reviers, M.M., Martinat, N. \& Blanc, M.R. (1981b) A reinvestigation of hypothalamic pituitary testicular interactions: simultaneous changes in tissues and plasma levels of gonadotrophins, prolactin, testosterone and hypothalamic LHRH after bilateral orchidectomy and cryptorchidism. Reprod. Nutr. Develop. 21, 455-465.

de Kretser, D.M., Kerr, J.B., Rich, K.A., Risbridger, G. \& Dubos, M. (1980) Hormonal factors involved in normal spermatogenesis and following the disruption of spermatogenesis. In Testicular Development, Structure and Function, pp. 107-115. Eds A. Steinberger \& E. Steinberger. Raven Press, New York.

Eskay, R.L., Mical, R.S. \& Porter, J.C. (1977) Relationship between luteinizing hormone releasing hormone concentration in hypophysial portal blood and luteinizing hormone release in intact, castrated, and electrochemically-stimulated rats. Endocrinology 100, 263-270.

Franchimont, P., Millet, D., Vendrely, E., Letawe, J., Legros, I.J. \& Netter, A. (1972) Relationship between spermatogenesis and serum gonadotropin levels in azoospermia and oligospermia. J. clin. Endocr. Metab. 34, 1003-1008.

Gillet, J. \& Laporte, P. (1973a) Action du busulfan et de la FSH sur le tube séminifère de rat: effets morphologiques et cellulaires. Archs Anat. microsc. Morph. 62, 385-398.

Gillet, J. \& Laporte, P. (1973b) Altérations épididy- 
maires chez le rat après traitement in utéro au busulfan. C. r. Séanc. Soc. Biol. 167, 706-714.

Gomes, W.R. \& Jain, S.K. (1976) Effect of unilateral and bilateral castration and cryptorchidism on serum gonadotrophins in the rat. J. Endocr. 68, 191-196.

Gomes, W.R., Hall, R.W., Jain, S.K. \& Boots, L.R. (1973) Serum gonadotropin and testosterone levels during loss and recovery of spermatogenesis in rats. Endocrinology 93, 800-809.

Hagenäs, L., Ritzén, E.M., Svensson, J., Hansson, V. \& Purvis, K. (1978) Temperature dependence of Sertoli cell function. Int. J. Androl., Suppl. 2, 449-458.

Hall, R.W. \& Gomes, W.R. (1973) Testosterone levels in the serum and testis of growing rats following prenatal exposure to busulfan. J. Reprod. Fert. 35, 131-134.

Haour, F. \& Saez, J.M. (1977) hCG-dependent regulation of gonadotropin receptor sites: negative control in testicular Leydig cells. Molec. cell. Endocr. 7, 1724.

Hochereau-de Reviers, M.T., Loir, M. \& Pelletier, J. (1976) Seasonal variations in the responses of the testis and $\mathrm{LH}$ levels to hemicastration of adult rams. J. Reprod. Fert. 46, 203-209.

Hochereau-de Reviers, M.T., Blanc, M.R., Cahoreau, C., Courot, M., Dacheux, J.L. \& Pisselet, C., (1979) Histological testicular parameters in bilateral cryptorchid adult rams. Annls Biol. anim. Biochim. Biophys. 19, 1141-1146.

Jackson, H. (1970) Antispermatogenic agents. Br. med. Bull. 26, 79-86.

Jackson, H., Partington, M. \& Fox, B.W. (1962) Effects of busulfan (Myleran) on the spermatogenic population of the rat testis. Nature, Lond. 194, 1184-1185.

Lowry, O.H., Rosebrough, J., Farr, A.L. \& Randall, R.J. (1951) Protein measurement with the folin phenol reagent. J. biol. Chem. 193, 265-275.

Martinat, N., Hall, H., Ravault, J.P. \& Dubois, M.P. (1979) Purification of rat prolactin: development of an homologous radioimmunological assay and com- parison with the NIAMDD system. Annls Biol anim. Biochim. Biophys. 19, 1771-1788.

Negri, A. \& Gay, V.L. (1976) Differing effects of comparable serum concentration on gonadotropin secretion in pre- and postpubertal orchidectomized rats. Biol. Reprod. 15, 375-380.

Orth, J.M. (1982) Proliferation of Sertoli cells in fetal and postnatal rats: a quantitative autoradiographic study. Anat. Rec. 203, 485-492.

Payne, A.H., Kelch, R.P., Murono, E.P. \& Kerlan, J.T. (1977) Hypothalamic pituitary and testicular function during sexual maturation in the male rat. $J$. Endocr. 72, 17-26.

Rich, K.A. \& de Kretser, D.M. (1977) Effect of differing degrees of destruction of the rat seminiferous epithelium on levels of serum follicle stimulating hormone and androgen binding protein. Endocrinology 101, 959-968.

Rich, K.A. \& de Kretser, D.M. (1979) Effect of fetal irradiation on testicular receptors and testosterone response to gonadotrophin stimulation in adult rats. Int. J. Androl. 2, 343-352.

Schanbacher, B.D. (1980) Androgen secretion and characteristics of testicular hCG binding in cryptorchid rats. J. Reprod. Fert. 59, 145-150.

Vendrely, E., Guerillot, C. \& Dalage, C. (1972) Variations saisonnières de l'activité des cellules de Sertoli et de Leydig dans le testicule du Hamster doré. Etude caryométrique. C. r. hebd. Séanc. Acad. Sci. Paris D 275, 1143-1146.

Viguier-Martinez, M.C. (1976) Plasma LH response to LH-RH injection in immature intact, castrated and cyproterone-treated male rats. J. Reprod. Fert. 48, 195-197.

Viguier-Martinez, M.C., Hochereau-de Reviers, M.T., Barenton, B. \& Perreau, C. (1983) Effect of a nonsteroidal antiandrogen, Flutamide, on the hypothalamo-pituitary axis, genital tract and testis in growing male rats: endocrinological and histological data. Acta endocr., Copenh. 102, 299-306.

Received 8 April 1983 